\title{
Determinants of Choice of Climate Change Adaptation Strategies in Northern Ghana
}

\author{
Franklin Nantui Mabe ${ }^{1, *}$, Gifty Sienso $^{1} \&$ Samuel Donkoh ${ }^{1}$ \\ ${ }^{1}$ Department of Agricultural and Resource Economics, Faculty of Agribusiness and \\ Communication Sciences, University for Development Studies, Tamale, Ghana \\ *Corresponding author: Department of Agricultural and Resource Economics, Faculty of \\ Agribusiness and Communication Sciences, University for Development Studies, Nyankpala \\ Campus, P. O. Box 1882, Tamale, Ghana. E-mail: raxffranklin@gmail.com
}

Received: August 11, 2014 Accepted: October 20, $2014 \quad$ Published: November 30, 2014

doi:10.5296/rae.v6i4.6121 URL: http://dx.doi.org/10.5296/rae.v6i4.6121

\begin{abstract}
This paper used binary logistic regression model to analyze factors that affect the choice of climate change adaptation strategies of farmers in Northern Ghana. Using semi-structured questionnaires, 155 farmers were randomly sampled from purposively selected three Northern Regions in Ghana. The empirical results of the binary logistic regression models revealed different effects of the factors on farmer's choice of adaptation strategies. Farming experience, farm income, access to phones, mixed farming, farmers' perception on reduction in rainfall amount and access to weather information significantly and positively affects the choice of at least five climate change adaptation strategies. Following the findings of this study, agricultural extension service should be intensified through organization of adult education programmes or field schools for farmers to educate them on some climate change adaptation strategies. Agro climatic information centers should be established at vantage points in farming communities to enable farmers seek for information to help them revise their climate change adaptation decisions for specific time and agricultural activity. Lastly, affordable climate change adaptation technologies should be designed and make available to poor farmers to adopt.
\end{abstract}

Keywords: Adaptation strategies, climate change, logit regression and Northern Ghana 


\section{Introduction}

Climate change has become a great concern to farmers especially those found in tropical regions like Africa. According to Deressa (2008) and Kurukulasuriya and Mendelsohn (2006), agriculture in Africa is negatively affected by climate change and care need to be taken to avert this situation. Farmers in Sub-Saharan African countries are adversely affected by the current changes in climatic conditions. Ontoyin (1993) and Stephens (1996) empirically established the evidence of climate change in Ghana by quantifying the significant changes in temperature. Stephens (1996) and Stutley (2010) indicated that high temperatures reduce crop yield in Ghana. Ghana as a tropical country is gradually experiencing the impact of climate change on its agriculture. A study conducted by Mabe (2011) indicated that climate change is evident in the Northern Region of Ghana. Farmers in the Northern Ghana which comprises Upper West, Upper East, Northern and some parts of Brong Ahafo and Volta Regions are likely to be the most affected due to the harsh weather conditions which are experienced in those areas.

Tonah (1993) and Mensah-Bonsu (2003) established that planting period for crops in Northern Ghana has changed from early April in 1960s to late April or early May in recent years due to the unpredictable nature of rains and the changing environmental conditions especially rainfall amounts and distribution. Smallholder farmers in Northern Ghana are likely to experience the negative effects of climate change in recent years. This is due to the fact that smallholder farmers lack the capacity to adequately adapt to the changing climatic conditions which are bedeviling the regions. Irrespective of this, some of the farmers in Northern Ghana adapt to climate change by planting early maturing crop varieties, use of fertilizers, farming on fallowed land and mulching with the main purpose of reducing the impacts of climate change on agricultural production (Mabe et al., 2012).

Mendelsohn (1998) and Smit and Skinner (2002) have demonstrated that without adaptation, agricultural production will be severely affected by climate change with the resultant effects of making farmers more vulnerable. Farmers' adaptation to climate change is based on their expectation about the possible benefits that may be generated in future. This means there are some costs associated with adaptation to climate change. This cost that one incur in adapting to climate change is what Maddison (2006) called "traditional adaptation cost". The use of a particular adaptation strategy can be linked to so many factors. What are left unknown are the determinants of the choice of the various adaptation strategies that farmers use in minimizing the effects of climate change on agricultural production.

The decision of a farmer to use an adaptation strategy to mitigate the effect of climate change depends largely on certain socio-economic factors which need to be known. Factors that affect farmers' adaptation decision are very important in designing policies to promote effective adaption in the agricultural sector. Some farmers are able to adjust and adapt better than others depending on farm management practices, land management practices, farm characteristics, livelihood strategies and farmer socio-demographic characteristics. The understanding of how the various components of these factors affect farmers' decision to choose a particular climate change adaptation strategy is very necessary considering of the 
choice of livelihood strategies to be pursued in the Northern Ghana. Knowing the determinants of the choice of climate change adaptation strategies is very vital in developing intervention measures on those key determinants perceived to improve farmers' adaptive capacities. This study will quantify the magnitude and direction of the factors that affects the adoption of the major adaptation strategies by farmers.

\section{Methodology}

\subsection{Theoretical Framework}

The decision of farmers who perceived climate change to adopt or not to adopt a particular adaptation strategy depends on the utility associated with each decision. Therefore, the analytical framework of the determinants of farmers' adaptation strategies falls under theory of utility maximization. The decision of farmers to adopt or not to adopt any particular adaptation strategy (technology) to reduce the effects of climate change on agricultural production is characterized by certain socioeconomic factors, farm characteristics, changes in climatic factors (Deressa et al., 2008).

A farmer chooses an adaptation method by considering the weighted expected utility that he or she will derive from adopting that strategy. A farmer uses an adaptation strategy $\mathrm{j}$ if and only if he or she perceives that the utility or net benefit from using that adaptation strategy is significantly greater than the situation of not using it. The utility associated with such decisions are not directly observed. Meanwhile, the choices of adaptation measures of farmers are observed. The choices of farmers are unordered and hence their decisions on adaptation strategies are linked to random utility maximization.

Assume that $U_{j}$ is the expected utility that a farmer will gain from using adaptation strategy $j$ whereas $U_{k}$ is the expected utility for not choosing adaptation strategy $j$ but rather $k$. The linear random utility model of adapting to climate change by choosing $j^{\text {th }}$ adaptation strategy $\left(U_{j}\right)$ can be expressed as a function of explanatory variables $X_{i}$ as shown below.

$$
U_{i j}=x_{i} \beta_{j}^{\prime}+\mu_{j}
$$

Also, the linear random utility model for $i^{\text {th }}$ farmer who does not use $j^{\text {th }}$ adaptation strategy but rather $k^{\text {th }}$ adaptation strategy is given by:

$$
U_{i k}=x_{i} \beta_{k}^{\prime}+\mu_{k}
$$

Where $x_{i}$ is a vector of explanatory variables (socioeconomic factors, farm characteristics, perception of farmers on changes in climatic factors), $\beta_{j}^{\prime}$ and $\beta_{k}^{\prime}$ are vectors of parameters for choosing $j^{\text {th }}$ and $k^{\text {th }}$ adaptation strategy respectively. Also, $\mu_{j}$ and $\mu_{k}$ are error terms for choosing $j^{\text {th }}$ and $k^{\text {th }}$ adaptation strategy respectively. The error terms in the above equations are assumed to be normally independently and identically distributed (Gujarati, 2006). Following the commonly used adaptation strategies identified in the research conducted by Mabe (2012), Deressa et al. (2008) and Bryan et al. (2011), and the preliminary survey by the 
researchers, the adaptation strategies that are considered in this study are changing crop varieties, changing planting dates, planting of trees, destocking, increase farm size, application of fertilizer, farming on fallowed land, diversification and mulching.

If a farmer chooses to adopt $j$ th adaptation strategy to climate change, then the expected utility that the farmer gets is greater than the expected utility for not using that strategy. According to Falco et al. (2007), a farmer chooses adaptation strategy $j$ over adaptation strategy $k$ if and only if the expected utility from adaptation strategy $j$ is greater than that of $k$.

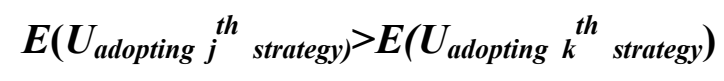

The actual inequality is expressed as:

$$
U_{i j}\left(x_{i} \beta_{j}^{\prime}+\mu_{j}\right)>U_{i k}\left(x_{i} \beta_{k}^{\prime}+\mu_{k}\right)
$$

Where $_{j} \neq k$

The probability of adapting to climate change by choosing $j t h$ adaptation strategy can be expressed as:

$$
\begin{gathered}
P(U=1 \mid x)=P\left\{\left(x_{i} \beta_{j}^{\prime}+\mu_{j}\right)>\left(x_{i} \beta_{k}^{\prime}+\mu_{k}\right)\right\} \\
P(U=1 \mid x)=P\left\{\left(x_{i} \beta_{j}^{\prime}+\mu_{j}\right)-\left(x_{i} \beta_{k}^{\prime}+\mu_{k}\right)>0 \mid x\right\} \\
P(U=1 \mid x)=P\left\{x_{i}\left(\beta_{j}^{\prime}-\beta_{k}^{\prime}\right)+\left(\mu_{j}-\mu_{k}\right)>0 \mid x\right\} \\
P(U=1 \mid x)=P\left\{\left(\beta^{*} x_{i}+\mu^{*}\right)>0 \mid x\right\} \\
P(U=1 \mid x)=F\left(\beta_{0}+\beta_{1} X_{1}+\cdots+\beta_{n} X_{n}\right)
\end{gathered}
$$

Where $P$ is a probability function, $\mu^{*}=\mu_{j}-\mu_{k}$ is a random term, $\beta^{*}=\beta_{j}-\beta_{k}$ is a vector of unknown parameters and $F$ is the cumulative distribution function of $\mu^{*}$. The distribution of $F$ depends on the distribution of the stochastic random noise, $\mu^{*}$.

\subsection{Empirical Model}

The dependent variable is binary choice because there are two options for each farmer. This binary choice is dummied as 1 if a farmer chooses $j^{\text {th }}$ adaptation strategy in response to perceived climate change and 0 otherwise (Bryan et al., 2011). Therefore, this research employs binary logit model in analyzing the determinants of farmers' decision to choose a particular adaptation strategy. The outstanding advantage of this model is that it allows one to analyze decisions and determine the associated probabilities for the choice of a particular adaptation strategy. This study analyses each adaptation strategy separately and independently unlike the use of multinomial logit model. This is to eliminate the effects of the choice of one adaptation strategy on the other.

Suppose $Y$ is the adaptation option to climate change which is a random variable and $\mathrm{X}$ is the 
socioeconomic factors, farm characteristics etc. For such a dichotomous outcome, the inferential statistical analysis used for this study is logistic model (Fosu-Mensah, 2010). Acquah (2011) indicated that the effect of $X$ on the response probabilities, $P(y=j / x)$ can be estimated by using binary logit model which is expressed as:

$$
\begin{gathered}
P\left(Y_{i} \mid X\right)=F\left(Z_{j}\right)=\frac{e^{Z_{i}}}{1+e^{Z_{i}}}=\frac{1}{1+e^{-Z_{i}}} \\
P\left(Y_{i}=j / X_{i}\right)=F\left(Z_{j}\right)=\frac{e^{z_{j}}}{1+e^{z_{j}}}=\frac{1}{1+e^{-z_{j}}} \\
Z_{i}=\beta_{0}+\beta_{1} X_{1 i}+, \ldots,+\beta_{n i} X_{n i}+\mu_{i}
\end{gathered}
$$

According to Apata et al. (2009), the specific binary logit model is given as:

$$
\ln \left[\frac{P_{j}}{1-P_{j}}\right]=\beta_{0}+\beta_{1} X_{1 i}+, \ldots,+\beta_{n i} X_{n i}+\mu_{i}
$$

$\mathrm{n}=1,2, \ldots, 17$

Table 1 shown below depicts the explanatory variables and how they are measured. Meanwhile,

\begin{tabular}{|c|c|c|c|}
\hline $\begin{array}{l}\text { Explanatory } \\
\text { variable }\end{array}$ & Description & Measurement & $\begin{array}{c}\text { Slope } \\
\text { coefficient }\end{array}$ \\
\hline $\mathrm{X}_{1}$ & Age & Years & $\beta_{1}$ \\
\hline $\mathrm{X}_{2}$ & Credit access & 1 if access, 0 otherwise & $\beta_{2}$ \\
\hline$X_{3}$ & $\begin{array}{l}\text { Distance of farmers' residence from } \\
\text { district capital }\end{array}$ & Kilometers $(\mathrm{Km})$ & $\beta_{3}$ \\
\hline $\mathrm{X}_{4}$ & Education up to class six and above & 1 if access, 0 otherwise & $\beta_{4}$ \\
\hline $\mathrm{X}_{5}$ & Farming experience & $\begin{array}{l}\text { Number of years of } \\
\text { farming }\end{array}$ & $\beta_{5}$ \\
\hline $\mathrm{X}_{6}$ & $\begin{array}{l}\text { Extension contact (at least three visits } \\
\text { with training annually) }\end{array}$ & 1 if access, 0 otherwise & $\beta_{6}$ \\
\hline $\mathrm{X}_{7}$ & Farm income & Ghana cedis $(\mathrm{GH} \phi)$ & $\beta_{7}$ \\
\hline $\mathrm{X}_{8}$ & Farm size & Acres & $\beta_{8}$ \\
\hline $\mathrm{X}_{9}$ & Gender & 1 if male, 0 otherwise & $\beta_{9}$ \\
\hline $\mathrm{X}_{10}$ & Household size & Numbers & $\beta_{10}$ \\
\hline $\mathrm{X}_{11}$ & Perception on increase in temperature & 1 if increase, 0 otherwise & $\beta_{11}$ \\
\hline $\mathrm{X}_{12}$ & Phone access (owning a phone) & 1 if access, 0 otherwise & $\beta_{12}$ \\
\hline $\mathrm{X}_{13}$ & Marital status & 1 if married, 0 otherwise & $\beta_{13}$ \\
\hline $\mathrm{X}_{14}$ & Either mixed farming or cropping & 1 if practice, 0 otherwise & $\beta_{14}$ \\
\hline $\mathrm{X}_{15}$ & Non-farm income & Ghana cedis $(\mathrm{GH} \phi)$ & $\beta_{15}$ \\
\hline $\mathrm{X}_{16}$ & Perception on reduction in rainfall & 1 if reduce, 0 otherwise & $\beta_{16}$ \\
\hline $\mathrm{X}_{17}$ & Weather information access & 1 if access, 0 otherwise & $\beta_{17}$ \\
\hline
\end{tabular}
the apriori expectations of the explanatory variables are illustrated in table 2 under the appendix 1

Table 1. Farmer Household Characteristic Affecting the Choice of Adaptation Strategy 


\subsection{Data Collection and Study Area}

A farmer household survey was conducted in July, 2012. Structured and unstructured questionnaires were used to collect primary data from 155 farmers in Northern Ghana. This sample size was chosen based on the fact that, in Ghana there is no record on the number of farmers in any of the regions. The farmers were randomly selected from Upper West, Upper East and Northern Regions of Ghana. In Upper West Region, farmers were sampled from Lawra and Wa East Districts. Farmers in Bongo and Garu-Tempane Districts in Upper East Region were sampled whereas farmers from Saboba, West Gonja and Karaga Districts were interviewed from Northern Region. The three regions were purposely selected due to the fact that they form Northern Ghana with very harsh weather conditions. The districts, the communities and the farmers were selected by using simple random techniques. Figure 1 below shows the map of Ghana and the selected districts for the study. Farmers who perceived a change in climatic variables (temperature and rainfall) were presented with a list of adaptation strategies which were identified earlier from the study area during pretesting of the questionnaires and literature. Those who perceive climate change ticked the adaptation strategies that they adopt in mitigating the effects of climate change on agricultural production. The data was analyzed by using eViews.

When the country is divided horizontally into approximately two parts, the half part pointing to the north is called Northern Ghana. Northern Ghana is made up of the whole of Northern, Upper West and Upper East Regions. Meanwhile, small parts of Brong-Ahafo and Volta Regions are located in Northern Ghana. The agro climatic vegetation in the area is Sudan Savanna (found in Upper West and Upper East Regions), Guinea Savanna (located in Northern Region and part of Brong-Ahafo and Volta Regions) and Transitional Zone (part of Brong-Ahafo Region). The pre-dominant occupation in the study area is farming. Food crops such as cereals (maize, rice, millet and sorghum etc.), root and tubers (cassava, yam and potato), legumes (cowpea, soya beans, Bambara beans and peanut etc.) and tree crops (mango, tick tree, Shea tree, cashew etc.) are grown in the area MLGRD (2006). Livestock comprising small and large ruminants (goats, sheep and cattle) and monogastrics (pigs, poultry, donkey and horses) are also reared for sale, prestige, sacrifice or domestic consumption. Relatively, Northern Ghana has very harsh weather condition as compare to Southern Ghana. 


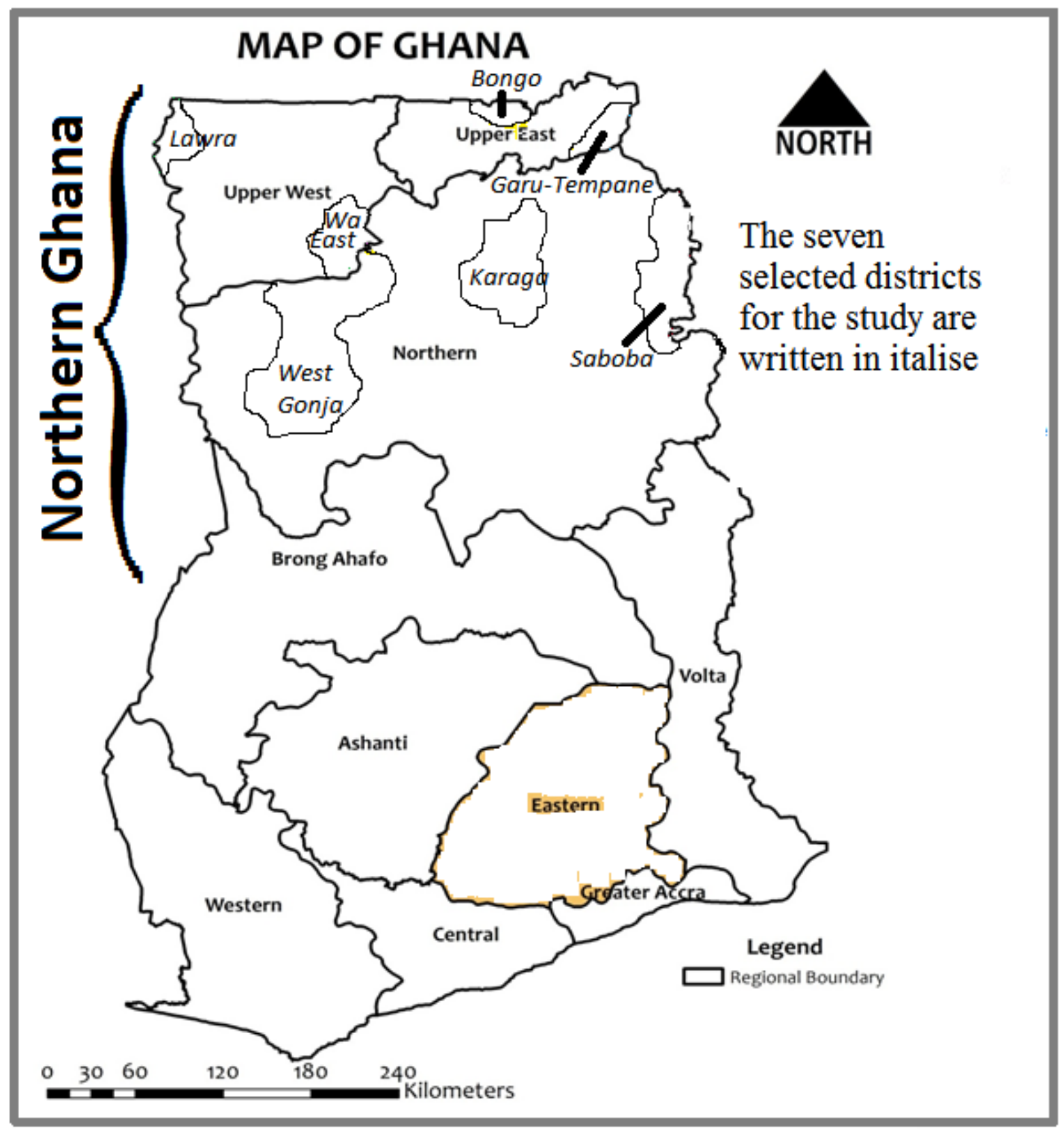

Figure 1. Map of Ghana Showing the Selected Districts for the Study

\section{Empirical Results and Discussion}

\subsection{Demographic Characteristics of the Respondents}

Table 3 under appendix 2 presents frequency of responses for the adaptation strategies used by farmers. Table 4 under appendix 3 shows the descriptive analysis of the continuous variables. The mean age of the respondents is 42 years whilst the mean number of years of farming experience is 15 (table 4 in appendix 3). The mean household size is 6 members per household. The minimum, maximum and mean farm sizes are 1.5, 13 and 4.82 acres 
respectively. Out of 155 farmers interviewed, 86 of them have access to weather information. The field data shows that majority (80) of the respondents have access to credit. Finally, the mean values of farm income, non-farm income and distance of farmer's residence from district capital are Ghф1,185.99, Ghф238.05 and 13.10Km respectively.

The descriptive statistics of discrete variables are shown in table 5 under appendix 4. From table 5, majority (81.94\%) of the respondents are males. Out of 155 farmers interviewed, $71.61 \%$ of them have access to mobile phones, $50.97 \%$ have access to extension service, $78.06 \%$ are married and $29.03 \%$ have minimum of primary school education. Also, majority; $70.32 \%$ of the respondents perceived that annual amount of rainfall has reduced. A greater percentage $(61.94 \%)$ of farmers perceived that weather condition is becoming warmer and warmer each year whereas others perceive otherwise.

\subsection{Econometric Results: Determinants of Adaptation Strategies}

Using binary logistic regression mode, the factors that significantly affect the choice of a particular adaptation strategy in minimizing the adverse impact of climate change on agricultural production were identified. To eliminate the possibility of interactions among the adaptation decisions of farmers, ten different binary logit regression models were ran for each adaptation strategy. The frequency of responses for adaptation strategies is illustrated in table 3 (appendix 2). The results of the maximum likelihood-binary logit (quadratic hill climbing) estimates are presented in table 6 below.

\subsubsection{Changing cropping calendar}

From table 6, three factors were found to significantly affect the change in cropping calendar as an adaptation strategy to climate change out of seventeen independent variables entered into the model. Household size is statistically significant at $10 \%$ probability level. Meanwhile, the negative sign and the marginal effect value imply that farmers with large household size have low probability of shifting cropping calendar as one of the adaptation strategies to climate change impact. This may be due to the fact that farmers with large household sizes have enough family labor to complete planting of crops within a very short period to prevent the possibility of planting late which might be affected by the changing climatic condition. This revelation is contradictory to what was revealed by Bryan et al. (2011). They observed insignificant effects of household size on changing planting dates.

The expectation of the study is met in relation to the effects of farmers' access to phone on the adoption of changing planting dates as an adaptation strategy. The probability value suggest that access to phone significantly affects the farmers decision of changing cropping calendar at all conventional levels. This implies that the probability of a farmer who has access to phone will be $40.11 \%$ greater than a farmer without access to phone. The justification is that farmers who have phones can easily get weather information through phones calls of people in cities on the expected dates of onset of rains and adjust the planting dates to coincide with this period.

The results of model 2 in table indicate that access to weather information significantly 
affects adaptation to climate change. Meanwhile, the negative sign of the marginal effects does not agree with the a priori expectation

\subsubsection{Changing crop varieties}

The socioeconomic factors which are identified from table 6 as determinants of decision of farmers to change crop varieties were age, farming experience, farm income and gender. The age of the respondent is significant at $10 \%$ and meets the a priori expectation implying that younger farmers are likely to adapt to climate change by changing crop varieties that they cultivate. Young farmers are energetic, innovative and risk loving, and as such are ready to use new and improve crop varieties which are drought resistant and early maturing. Farming experience is also significant at $10 \%$ and conforms to the expected direction of the effects. This means as one become more experienced in farming, the probability of one to change crop varieties increases more than a farmer with less farming experience. With experience farmers get to know the unproductivity and unreliability of crop varieties and thereby making them to adopt new crop varieties than less experience farmers.

Also, the study observed a positive relationship between amount of farm income realized and the change of crop varieties in response to climate change. The significant level at 5\% probability and the positive sign infers that the larger the farm income realized, the higher the probability for farmers to change crop varieties. Gender is statistically significant at $10 \%$ and follows the a priori expectation. This therefore signifies that males have lower probability of changing crop varieties as an adaptation strategy to climate change than female farmers. This observation is consistent with what Sofoluwe et al. (2011) observed in their research on farmer's perception and adaption to climate change in Osun State, Nigeria. This could be that female farmers do easily accept new innovations such as introduction of new crop varieties. Meanwhile, Bryan et al. (2011) observed an insignificant effect of gender of household head on changing crop varieties in response to climate change.

\subsubsection{Destocking}

From table 6, age, credit access, farmers' residence distance from district capital, access to education, farming experience, perception on increase in temperature, mixed farming, nonfarm income and access to weather information are identified as factors affecting farmers' decision of destocking of their livestock. Age of farmers is significant at $1 \%$ and toes the line of a priori expectation that older farmers tend to destock their livestock more than younger farmers. This is logical because the more older the farmer becomes, the less energetic he/she is to still maintain the same number of livestock he/she used to keep.

The distance of the place of residence of the farmer from the district capital significantly affects farmers' decision of destocking. The positive sign of the marginal effect implies that the farther the residence of the farmer from the district capital, the higher the likelihood that the farmer will destock some of the livestock to a manageable level. This revelation contradicts the expectation of the researcher. Also, since the coefficient of education is negative and significant at $10 \%$, it means that the probability of farmers with education to destock their livestock is lower than that of farmers without education. The deduction made 
from this observation is that farmers with education have managerial skills to manage a greater number of stocks of livestock without encountering a greater negative effect of climate change.

The findings of farming experience meet the a priori expectation and can be justified by the fact that less experienced farmers may be risk adverse and henceforth destock their livestock so as to reduce the probability of livestock failure. Also, farmers who perceived an increase in temperature are likely to destock their livestock. This is so in the sense that farmers who perceive an increase in temperature may have the fear that the livestock will be affected by high temperature.

Both mixed farming and nonfarm income are significant at $10 \%$ and meet the a priori expectation, meaning farmers who have large nonfarm income and practice mixed farming have lower probabilities of destocking their livestock than those who do otherwise. With high nonfarm incomes farmers are able to buy feeds, drugs, construct proper housing facility to prevent the adverse effects of climate change on their livestock.

Finally, weather information is significant at $5 \%$ and is in conformity to a prior expectation. The positive sign suggest that farmers who have access to weather information are likely to destock their livestock so as to limit the effect of climate change on the animals. 


\section{Macrothink}

Table 6. Results of maximum likelihood-binary logit models indicating factors affecting the choice of adaptation strategies

\begin{tabular}{|c|c|c|c|c|c|c|c|c|c|c|}
\hline \multirow[b]{3}{*}{ Determinants } & \multicolumn{10}{|c|}{ Adaptation strategies (Marginal effects) } \\
\hline & Model 1 & Model 2 & Model 3 & Model 4 & Model 5 & Model 6 & Model 7 & Model 8 & Model 9 & Model 10 \\
\hline & $\begin{array}{l}\text { Changing } \\
\text { planting } \\
\text { dates }\end{array}$ & $\begin{array}{l}\text { Changing } \\
\text { crop } \\
\text { varieties }\end{array}$ & Destocking & Diversification & Fallowing & Fertilization & $\begin{array}{l}\text { Increase in } \\
\text { farm size }\end{array}$ & Mulching & $\begin{array}{l}\text { Planting of } \\
\text { trees }\end{array}$ & $\begin{array}{l}\text { At least five } \\
\text { adapt } \\
\text { strategies }\end{array}$ \\
\hline \multirow[t]{2}{*}{ Constant } & -1.0232 & 0.1110 & -1.7678 & -1.5757 & -0.4999 & -0.0458 & 0.0489 & 0.1164 & -0.8652 & -2.3056 \\
\hline & $(0.0103$ & $(0.7703)$ & $(0.000)$ & $(0.0019)$ & $(0.2535)$ & $(0.9099)$ & $(0.9067)$ & $(0.7885)$ & $(0.0374)$ & $(0.0009)$ \\
\hline \multirow[t]{2}{*}{ Age } & 0.0050 & -0.0189 & 0.0248 & 0.0148 & 0.0135 & -0.0130 & -0.0100 & -0.0318 & 0.0121 & -0.0018 \\
\hline & $(0.6260)$ & $(0.0538)^{*}$ & $(0.0070)^{* * *}$ & $(0.2059)$ & $(0.2335)$ & $(0.2086)$ & $(0.3552)$ & $(0.0104)^{* *}$ & $(0.2674)$ & $(0.9072)$ \\
\hline \multirow[t]{2}{*}{ Credit access } & -0.0202 & 0.0939 & 0.3269 & -0.2177 & -0.0985 & 0.1253 & 0.1041 & -0.1999 & -0.0010 & -0.1027 \\
\hline & $(0.8591)$ & $(0.4125)$ & $(0.0062)^{* * *}$ & $(0.0836)^{*}$ & $(0.4383)$ & $(0.2935)$ & $(0.4146)$ & $(0.1478)$ & $(0.9939)$ & $(0.5590)$ \\
\hline Distance of farmers' residence & 0.0099 & 0.0050 & 0.0180 & 0.0082 & 0.0053 & 0.0063 & -0.0208 & -0.0003 & -0.0028 & 0.0071 \\
\hline from district capital & $(0.1552)$ & $(0.4747)$ & $(0.0076)^{* * *}$ & $(0.3377)$ & $(0.4677)$ & $(0.3787)$ & $(0.0133)^{* *}$ & $(0.9692)$ & $(0.6953)$ & $(0.4777)$ \\
\hline \multirow[t]{2}{*}{ Education up to class size and above } & 0.1769 & -0.1430 & -0.2038 & 0.3078 & -0.2247 & -0.0205 & 0.0084 & 0.4381 & 0.1236 & 0.3058 \\
\hline & $(0.1877)$ & $(0.2986)$ & $(0.0751)^{*}$ & $(0.0815)^{*}$ & $(0.1247)$ & $(0.8774)$ & $(0.9497)$ & $(0.0031)^{* * *}$ & $(0.3538)$ & $(0.2438)$ \\
\hline \multirow[t]{2}{*}{ Farming experience } & 0.0162 & 0.0237 & -0.0173 & -0.0035 & -0.0167 & 0.0009 & 0.0003 & 0.0400 & -0.0077 & 0.0282 \\
\hline & $(0.1591)$ & $(0.080)^{*}$ & $(0.0793)^{*}$ & $(0.7879)$ & $(0.1651)$ & $(0.9365)$ & $(0.9793)$ & $(0.0021)^{* * *}$ & $(0.4900)$ & $(0.0697)^{*}$ \\
\hline \multirow[t]{2}{*}{ Extension contact } & 0.0446 & 0.0111 & 0.0423 & -0.0326 & 0.1879 & -0.1539 & -0.1643 & 0.1499 & -0.1990 & -0.0285 \\
\hline & $(0.6631)$ & $(0.9121)$ & $(0.6782)$ & $(0.7795)$ & $(0.0893)^{*}$ & $(0.1411)$ & $(0.1671)$ & $(0.1980)$ & $(0.0951)^{*}$ & $(0.8542)$ \\
\hline \multirow[t]{2}{*}{ Farm income } & 0.0001 & 0.0005 & 0.0001 & 0.0008 & 0.0002 & 0.0001 & 0.0003 & 0.0003 & 0.0003 & 0.0011 \\
\hline & $(0.6631)$ & $(0.0113)^{* *}$ & $(0.3805)$ & $(0.0033)^{* * *}$ & $(0.3736)$ & $(0.6324)$ & $(0.0527)^{*}$ & $(0.0596)^{*}$ & $(0.0638)^{*}$ & $(0.0007)^{* * *}$ \\
\hline \multirow[t]{2}{*}{ Farm size } & 0.0224 & -0.0596 & 0.0071 & -0.0414 & -0.1011 & 0.0398 & 0.0118 & -0.0361 & -0.0256 & -0.0679 \\
\hline & $(0.6301)$ & $(0.2139)$ & $(0.8535)$ & $(0.5312)$ & $(0.0423)^{* *}$ & $(0.3698)$ & $(0.8077)$ & $(0.4627)$ & $(0.5725)$ & $(0.4040)$ \\
\hline \multirow[t]{2}{*}{ Gender } & 0.1494 & -0.3746 & -0.1305 & 0.2433 & 0.0261 & -0.0109 & 0.0524 & -0.3825 & -0.2053 & -0.2213 \\
\hline & $(0.2778))$ & $(0.0102)^{* *}$ & $(0.3931)$ & $(0.1385)$ & $(0.8671)$ & $(0.9320)$ & $(0.7465)$ & $(0.0251)^{* *}$ & $(0.2327)$ & $(0.4147)$ \\
\hline
\end{tabular}




\section{Continuation of table 6}

\begin{tabular}{|c|c|c|c|c|c|c|c|c|c|c|}
\hline \multirow[b]{3}{*}{ Determinants } & \multicolumn{10}{|c|}{ Adaptation strategies (Marginal effects) } \\
\hline & \multirow{2}{*}{$\begin{array}{l}\text { Model 1 } \\
\text { Changing } \\
\text { planting dates }\end{array}$} & \multirow{2}{*}{$\begin{array}{l}\text { Model } 2 \\
\text { Changing } \\
\text { crop varieties }\end{array}$} & \multirow{2}{*}{$\begin{array}{l}\text { Model } 3 \\
\text { Destocking }\end{array}$} & \multirow{2}{*}{$\begin{array}{l}\text { Model } 4 \\
\text { Diversification }\end{array}$} & \multirow{2}{*}{$\begin{array}{l}\text { Model } 5 \\
\text { Fallowing }\end{array}$} & \multirow{2}{*}{$\begin{array}{l}\text { Model } 6 \\
\text { Fertilization }\end{array}$} & \multirow{2}{*}{$\begin{array}{l}\text { Model } 7 \\
\text { Increase in } \\
\text { farm size }\end{array}$} & \multirow{2}{*}{$\begin{array}{l}\text { Model } 8 \\
\text { Mulching }\end{array}$} & \multirow{2}{*}{$\begin{array}{l}\text { Model } 9 \\
\text { Planting of } \\
\text { trees }\end{array}$} & Model 10 \\
\hline & & & & & & & & & & $\begin{array}{l}\text { At least five } \\
\text { adapt strategies }\end{array}$ \\
\hline \multirow[t]{2}{*}{ Household size } & -0.0435 & -0.0008 & -0.0081 & 0.0021 & 0.0063 & 0.0287 & -0.0211 & 0.0309 & -0.0258 & -0.0120 \\
\hline & $(0.0732)^{*}$ & $(0.9762)$ & $(0.6871)$ & $(0.9507)$ & $(0.7946)$ & $(0.2619)$ & $(0.4087)$ & $(0.2447)$ & $(0.2781)$ & $(0.7608)$ \\
\hline \multirow{2}{*}{$\begin{array}{l}\text { Increase in } \\
\text { temperature }\end{array}$} & 0.0777 & 0.0069 & 0.2426 & 0.1804 & 0.2134 & -0.1546 & -0.2635 & -0.2157 & 0.2303 & -0.0743 \\
\hline & $(0.4705)$ & $(0.9467)$ & $(0.0278)^{* *}$ & $(0.1121)$ & $(0.0573)^{*}$ & $(0.1622)$ & $(0.0365)^{* *}$ & $(0.0861)$ & $(0.0463)^{* *}$ & $(0.6489)$ \\
\hline \multirow[t]{2}{*}{ Phone access } & 0.4011 & 0.0682 & 0.0895 & 0.0758 & 0.2187 & -0.1535 & -0.0272 & 0.0606 & 0.0283 & 0.5072 \\
\hline & $(0.0021)^{* * *}$ & $(0.5769)$ & $(0.4672)$ & $(0.5903)$ & $(0.1180)$ & $(0.2695)$ & $(0.8394)$ & $(0.6669)$ & $(0.8395)$ & $(0.0116)^{* *}$ \\
\hline \multirow[t]{3}{*}{ Marital status } & & & & & & & & 0.3316 & & \\
\hline & -0.0752 & 0.1255 & 0.1096 & 0.0152 & -0.2999 & 0.1762 & -0.0124 & $(0.0181)^{*}$ & 0.1210 & 0.2333 \\
\hline & $(0.5274)$ & $(0.2639)$ & $(0.4080)$ & $(0.9097)$ & $(0.0283)^{* *}$ & $(0.0863)^{*}$ & $(0.9242)$ & * & $(0.3823)$ & $(0.1980)$ \\
\hline \multirow[t]{2}{*}{ Mixed farming } & 0.1858 & 0.2617 & -0.2393 & 0.0423 & 0.3764 & 0.3055 & 0.2097 & 0.1982 & 0.1794 & 0.5474 \\
\hline & $(0.1348)$ & $(0.9219)$ & $(0.0511)^{*}$ & $(0.7596)$ & $(0.0053)^{* * *}$ & $(0.0133)^{* *}$ & $(0.1478)$ & $(0.1781)$ & $(0.2110)$ & $(0.0076)^{* * *}$ \\
\hline \multirow[t]{2}{*}{ Non-farm income } & 0.0000 & 0.0000 & -0.0003 & -0.0001 & 0.0004 & 0.0000 & 0.0001 & -0.0004 & 0.0002 & -0.0001 \\
\hline & $(0.8285)$ & $(0.9219)$ & $(0.0718)^{*}$ & $(0.6336)$ & $(0.1096)$ & $(0.8993)$ & $(0.6118)$ & $(0.1023)$ & $(0.2750)$ & $(0.7454)$ \\
\hline \multirow{2}{*}{$\begin{array}{l}\text { Reduction } \\
\text { rainfall }\end{array}$} & 0.0616 & 0.1881 & 0.1352 & 0.1314 & 0.1211 & 0.0841 & 0.1812 & 0.1432 & -0.0807 & 0.3468 \\
\hline & $(0.6033)$ & $(0.1043)$ & $(0.2506)$ & $(0.3197)$ & $(0.3135)$ & $(0.4803)$ & $(0.1852)$ & $(0.3122)$ & $(0.5511)$ & $(0.0885)^{*}$ \\
\hline Mean dependent var & 0.6645 & 0.6903 & 0.2129 & 0.6839 & 0.6516 & 0.7355 & 0.3613 & 0.4903 & 0.3806 & 0.554839 \\
\hline Probability(LR stat) & $0.0009 * * *$ & $0.0015 * * *$ & $0.0003 * * *$ & $0.0000 * * *$ & $0.0001 * * *$ & $0.0001 * * *$ & $0.0000 * * *$ & $0.0000 * * *$ & $0.0001 * * *$ & $1.11 \mathrm{E}-16^{* * *}$ \\
\hline S.D. dependent var & 0.4737 & 0.4639 & 0.4107 & 0.4665 & 0.4780 & 0.4425 & 0.4425 & 0.5015 & 0.4871 & 0.498595 \\
\hline \multirow[t]{2}{*}{$\begin{array}{l}\text { McFadden } \\
\text { R-squared }\end{array}$} & 0.2076 & 0.2066 & 0.2759 & 0.3735 & 0.2411 & 0.2726 & 0.2726 & 0.2616 & 0.2265 & 0.547483 \\
\hline & Values in parent & esis are p-values. & $*, * *$ and $* *$ & represent $10 \%, 5 \%$ & and $1 \%$ levels & of significance & respectively & & & \\
\hline
\end{tabular}




\subsubsection{Diversification}

From table 6, diversification as an adaptation strategy to climate change depends on access to credit, access to education and farm income. Farmers who do not have access to credit tend to diversify their farms more than those who have access to credit. This outcome is ironic to what is expected.

The binary logit regression model indicates that farmers with at least primary school education seem to diversify agricultural production in response to climate change. This conclusion is made because access to at least primary school education is significant at $10 \%$ and positive. Farm income as a determinant of diversification is also significant at $1 \%$ and meets the researcher's expectation. This signifies that farmers with higher farm income are more likely to diversify their agricultural production, highlighting the role of surplus farm income use in venturing into new businesses or cultivating new type of crops or keeping livestock as a hedge against adverse effects of climate change.

\subsubsection{Fallowing}

The results of model 5 in table 6 indicates that access to extension contact and training, perception of farmers on increase in temperature and mixed farming positively and significantly affects the fallowing adoption decision. Farmers who have access to agricultural extension services and training tend to allow their lands to fallow more than their counterpart without agricultural extension service. This is because farmers with extension contact may be educated by extension agents on the importance of land fallowing thereby making them to adopt the technology more as compare to farmers without extension contact.

Farmers who perceive an increase in temperature and practice mixed farming will have respective probabilities of 0.2134 and 0.3764 of allowing their land to fallow more than those who do otherwise. These conclusions are drawn from positive signs of the marginal effects and the significant levels of perception on increase in temperature and practicing of mixed farming. Gender and farm size are significant at 5\% probability levels each. The negative sign of the marginal effects of farm size implies that the smaller the farm size, the greater the decision of the farmers to adopt fallowing in response to climate change. As it conforms to the a priori expectation, one can deduce that farmers with smaller farm sizes have more uncultivated lands available thereby making them to move from the cultivated land to the uncultivated one for the former to fallow. On the other hand, farmers with large farm sizes have no or less uncultivated land available for them to move to for the previously cultivated one to fallow. The farm size in this study means the size of cultivated land.

\subsubsection{Fertilization}

Only three factors (marital status, mixed farming practices and access to weather information) significantly affect fertilization decision of farmers. Marital status and mixed farming are significant at $10 \%$ and $5 \%$ respectively. The probability of a married farmer to fertilize his crop is greater than that of an unmarried farmer by 0.1762 . This is due to the fact that a married farmer has more hands (husband and wife with or without children) to apply fertilizer 
thereby making him/her have higher probability of applying fertilizer than the unmarried farmer with smaller household size.

Even though, mixed farming is significant; it is not in conformity to the a priori expectation. Access to weather information is significant at 5\% and positively affects the farmers' fertilization decision. The probability of farmers with access to weather information to apply fertilizer is higher than those without weather information. The reason for this outcome is that farmers with weather information may know the consequences of not applying fertilizer due to adverse effects of climate change on soil fertility thereby making them to do otherwise to get higher yield.

\subsubsection{Increase in farm size}

Out of the seventeen explanatory variables considered in this research, distance of residence of farmers from district capital, farm income and perception of farmers on increase in temperature have substantial effect on the decision of farmers to increase farm size. These deductions are made from logistic regression model results indicated in table 6. Out of these three factors, it is only farm income that meets the expected direction of the sign of the effects. Farmers with large farm income have higher probability of increasing farm size. This is meaningful because a farmer with more farm income expands his or her farm by using part of this income. This decision is to increase the output from the farm so as to compensate for the decrease yield associated with climate change. Farmers who stay far away from district capital as well as those who perceive high temperature in recent days have lower probability of increasing farm size.

\subsubsection{Mulching}

Mulching decision of farmers gave some noteworthy findings. Table 6 shows that age, education, farming experience, farm income, gender and marital status of respondents are significant determinants of mulching decisions of farmers. A famer with more farming experience and large farm income is more likely to apply mulching as an adaptation strategy to climate change. The binary logit regression results show that male farmers have low likelihood of adapting to climate change by mulching whereas married farmers have higher probability of applying mulch to decrease the adverse effects of climate change on agricultural production. This could be that married couples have more hands to help in the mulching as this adaptation strategy is labour intensive and calls for more responsibilities. Meanwhile, as the age of the farmer increases, the lower the probability of the farmer to adapt to climate change by applying mulching. The reason for these findings is that as one grows old, ones labour productivity decreases thereby making one to shed what is perceived unimportance cultural practice of farming (thus mulching). Meanwhile, as educated farmers know the importance of mulching; their probability of mulching is higher than those without at least primary education by 0.4381 .

\subsubsection{Planting of trees}

The factors that affect farmers' decision to plant trees to reduce the effects of climate change 
on agricultural production are extension contact, farm income, farmers' perception on increase in temperature and farmers' access to weather information (table 6). Farmers who perceived an increase in temperature over the years have higher probability of planting trees. Additionally, high farm income farmers are more likely to plant trees than low farm income farmers. All these findings are in conformity to their respective hypotheses. Large farm income farmers who have access to weather information and perceived an increase in atmospheric temperature over the years invest some of their large farm incomes on planting of trees. The canopies of these trees are expected to reduce the extreme high temperature reaching the crops so as to reduce its effects. The reverse of the expected outcome of the sign which shows the relationship between planting of trees and extension contact is that farmers with extension contact are more likely to reject tree planting as an adaptation to climate change.

\subsubsection{Factors affecting farmers' decision of using at least five adaptation strategies}

Farming experience, farm income, access to phones, mixed farming, perception on reduction in rainfall amount and access to weather information are significant determinants of the decision of farmers to use at least five adaptation strategies (table 6). Farmers with more farming experience, large farm size, access to phone and access to weather information have higher probability of using at least five climate change adaptation strategies. Additionally, farmers who perceive a decrease in rainfall amount and practice mixed farming have higher likelihood of using a minimum of five adaptation strategies to minimize the adverse effects of climate change on their agricultural production activities than farmers who do otherwise.

\section{Conclusions and Recommendations}

This study analyses the effects of socioeconomic characteristics, farm characteristics and climate change information on the choice of climate change adaptation strategies in Northern Ghana. The study used binary logit regression model to identify the factors that significantly affects the choice of an adaptation strategy. The marginal effects estimated from the logit model showed the direction of the effects of the explanatory variables on the choice of the adaptation strategies. In the study, the following adaptation strategies were identified during preliminary data collection and conform to literature: changing crop varieties, changing planting dates, planting of trees, destocking, increase farm size, application of fertilizer, farming on fallowed land, diversification and mulching.

The findings of the logistic regression results indicate that each of the explanatory very affects the adoption decision of each of the adaption strategies to climate change differently. Conclusively, farming experience, farm income, access to phones, mixed farming, perception on reduction in rainfall amount and access to weather information significantly and positively affects the choice of at least five climate change adaptation strategies.

Following the findings of this study, agricultural extension service should be intensified through organization of adult education programmes or field schools for farmers to educate 
them on some climate change adaptation strategies. Government should mandate stakeholders in disseminating weather and agricultural extension information to establish agro climatic information centers at vantage points in farming communities to enable farmers to source for information to help them revise their climate change adaptation decisions for specific time and specific agricultural activity. As farmers with high farm income are able to adapt more to climate change, affordable climate change adaptation technologies should be designed and made available to poor farmers to adopt.

\section{References}

Acquah, H. D. (2011). Farmers Perception and Adaptation to Climate Change: A Willingness to Pay Analysis. Journal of Sustainable Development in Africa, 13(5), 150-161.

Apata, T. G., \& Samuel. K. D. (2009). Analysis of Climate Change Perception and Adaptation among Arable Food Crop Farmers in South Western Nigeria. A paper presented at the International Association of Agricultural Economists' 2009 Conference, Beijing, China, August 16-22, 2009.

Bryan, E., Ringer, C., Okoba, B., Roncoli, C., Silvestri, S., \& Herrero, M. (2011). Adapting Agriculture to climate change in Kenya: Household and community strategies and determinants. Kenya.

Deressa, T. T. (2008). Analysis of Perception and Adaptation to Climate Change in the Nile Basin of Ethiopia. Centre for Environmental Economics and Policy for Africa (CEEPA). University of Pretoria.

Deressa, T. T., Hassan, R. M., Ringler, C., Alemu, T., \& Yesuf, M. (2008). Analysis of the Determinants of Farmers' choice of Adaptation Methods and Perceptions of Climate Change in the Nile Basin of Ethiopia. International Food Policy Research Institute. Washington, DC.

Falco, D. S., Yesuf, M., \& Kohlin, G. (2007). What Adaptation to Climate Change? Evidence from the Nile Basin, Ethiopia. International Food Policy Research Institute.

Fosu-Mensah, B. Y., Vlek, P. L. G., \& Manschadi, A. M. (2007). Farmers' Perception and Adaptation to Climate Change; A Case Study of Sekyedumase District in Ghana. Center for Development Research (ZEF), University of Bonn, Bonn.

Gujarati, D. N. (2006). Essentials of econometrics(3rd edition.). Boston: McGraw-Hill-Irwin.

Kurukulasuriya, P., \& Mendelsohn, R. (2006). Modeling Endogenous Irrigation: The Impact of Climate Change on Farmers in Africa. Center for Environmental Economics and Policy in Africa (CEEPA) Discussion Paper No. 8. Special Series on Climate Change and Agriculture in Africa.

Mabe, F. N. (2011). The Effects of Climate Change on Rice Production: Adaptations of Farmers in the Northern Region, Ghana. M.Phil. Thesis in Agricultural Economics. 
Department of Agricultural Economics and Agribusiness, Universty of Ghana, Legon.

Mabe, F. N., Sarpong, D. B., \& Osei-Asare, Y. (2012). Adaptive Capacities of Farmers to Climate Change Adaptation Strategies and their Effects on Rice Production in the Northern Region of Ghana. Russian Journal of Agricultural and Socio-Economic Sciences, 1(11), 9-17.

Maddison, D. (2006). The perception of and adaptation to climate change in Africa. CEEPA Discussion Paper No. 10. Centre for Environmental Economics and Policy in Africa, University of Pretoria, South Africa.

Mendelsohn, R. (1998). Climate-Change Damages: In Economics and policy issues in climate change, ed. W.D. Nordhaus. Resources for the Future: Washington, D.C.

Mensah-Bonsu, A. (2003). Migration and Environmental Pressure in Northern Ghana. Vrije University, Amsterdam.

MLGRD. (2006). Ghana Districts Repository. Ministry of Local Government and Rural Development (MLGRD). Maks Publications \& Media Services, Accra.

Ontoyin, Y. (1993). A Comparative Study of Temperature as a Climate Indicator for the Periods 1931-60 and 1961-90. Proceedings of a workshop on climate change and its impacts on water, ocean fishing and coastal zones. CSSIR, Accra, Ghana; 1993. 16-18th March, 1993 3-5.

Smit, B., \& Skinner, M. W. (2002). Adaptations options in agriculture to climate change: A typology. Mitigation and Adaptation Strategies for Global Change, 7, 85-114. http://dx.doi.org/10.1023/A:1015862228270

Sofoluwe, N. A., Tijani, A. A., \& Baruwa, O. I. (2011). Farmers' perception and adaptation to climate change in Osun State, Nigeria. African Journal of Agricultural Research, $6(20), 4789-479$

Stephens, C. S. (1996). Some Empirical Evidence of Global Warming in Ghana. Ghana Journal of Science, CSIR, Accra, 31-36.

Stutley, C. (2010). Innovation Insurance Product for the Adaptation to Climate Change (IIPACC) Project Ghana, Crop Insurance Feasibility Study 2010. Accra.

Tonah, S. (1993). The Development of Agropastoral Households in Northern Ghana: Policy Analysis, Project Appraisal and Future Perspectives, Breitenbal. 


\section{Appendix}

Appendix 1: Table 2 A priori expectation showing the relationship between the dependent and the independent variables

\begin{tabular}{|c|c|c|c|c|c|c|c|c|c|c|}
\hline \multirow[b]{2}{*}{ Determinants } & \multicolumn{10}{|c|}{ Adaptation strategies } \\
\hline & $\begin{array}{l}\text { Model } 1 \\
\text { Changing } \\
\text { planting } \\
\text { dates }\end{array}$ & $\begin{array}{l}\text { Model } 2 \\
\text { Changing } \\
\text { crop } \\
\text { varieties }\end{array}$ & $\begin{array}{l}\text { Model } 3 \\
\text { Destocking }\end{array}$ & $\begin{array}{l}\text { Model } 4 \\
\text { Diversification }\end{array}$ & $\begin{array}{l}\text { Model } 5 \\
\text { Fallowing }\end{array}$ & $\begin{array}{l}\text { Model } 6 \\
\text { Fertilization }\end{array}$ & $\begin{array}{l}\text { Model } 7 \\
\text { Increase } \\
\text { in farm } \\
\text { size }\end{array}$ & $\begin{array}{l}\text { Model } 8 \\
\text { Mulching }\end{array}$ & $\begin{array}{l}\text { Model } 10 \\
\text { Planting } \\
\text { of trees }\end{array}$ & $\begin{array}{l}\text { Model } 11 \\
\text { At least } \\
\text { five adapt } \\
\text { strategies }\end{array}$ \\
\hline Age & + & - & + & - & $+/-$ & $+/-$ & - & - & - & - \\
\hline Credit access & $+/-$ & + & - & + & $+/-$ & + & + & + & + & + \\
\hline Distance of farmers' residence from & & & & & & & & & & \\
\hline district capital & - & - & - & - & + & - & + & $+/-$ & $+/-$ & - \\
\hline $\begin{array}{l}\text { Education up to class size and } \\
\text { above }\end{array}$ & + & + & -- & + & $+/-$ & + & + & + & + & + \\
\hline Farming experience & + & + & - & + & + & $+/-$ & + & + & + & + \\
\hline Extension contact & + & + & - & + & + & + & + & + & + & + \\
\hline Farm income & $+/-$ & + & - & + & - & + & + & + & + & + \\
\hline Farm size & $+/-$ & - & - & + & + & - & $+/-$ & - & - & - \\
\hline Gender & - & - & $+/-$ & $+/-$ & - & $+/-$ & - & $+/-$ & - & $+/-$ \\
\hline Household size & $+/-$ & + & - & - & $+/-$ & + & + & + & + & + \\
\hline Increase in temperature & + & + & + & + & $+/-$ & $+/-$ & $+/-$ & + & + & + \\
\hline Phone access & + & + & $+/-$ & + & $+/-$ & + & + & + & + & + \\
\hline Marital status & $+/-$ & + & - & + & $+/-$ & + & + & + & + & + \\
\hline Mixed farming & $+/-$ & $+/-$ & - & + & $+/-$ & - & $+/-$ & - & $+/-$ & - \\
\hline Non-farm income & $+/-$ & + & - & + & + & + & + & + & + & + \\
\hline Reduction in rainfall & + & + & $+/-$ & + & $+/-$ & $+/-$ & $+/-$ & + & + & + \\
\hline Weather information & + & + & + & + & + & + & + & + & + & + \\
\hline
\end{tabular}


Appendix 2: Table 3. Frequency of responses for adaptation strategies

\begin{tabular}{lll}
\hline $\begin{array}{l}\text { Adaptation strategies } \\
\text { (Dependent variables) }\end{array}$ & $\begin{array}{l}\text { Frequency of farmers who } \\
\text { chose the } \\
\text { strategy }\end{array}$ & $\begin{array}{l}\text { Frequency of farmers who } \\
\text { adaptation } \\
\text { did not choose } \\
\text { adaptation strategy }\end{array}$ \\
\hline Changing planting dates & 103 & 52 \\
Changing crop varieties & 107 & 48 \\
Destocking & 33 & 122 \\
Diversification & 106 & 49 \\
Fallowing & 101 & 54 \\
Fertilization & 114 & 41 \\
Increase in farm size & 56 & 99 \\
Mulching & 76 & 79 \\
Planting of trees & 59 & 96 \\
Soil conservation & 75 & 80 \\
\hline
\end{tabular}

Appendix 3: Table 4 Descriptive statistics of continuous variables

\begin{tabular}{|c|c|c|c|c|}
\hline Variable & Minimum & Maximum & Mean & $\begin{array}{l}\text { Standard } \\
\text { deviation }\end{array}$ \\
\hline Age (years) & 18.00 & 64.00 & 42.00 & 11.35 \\
\hline $\begin{array}{l}\text { Experience in farming } \\
\text { (years) }\end{array}$ & 1.00 & 44.00 & 15.00 & 10.08 \\
\hline Household size (numbers) & 1.00 & 16.00 & 6.00 & 2.78 \\
\hline Farm size (acres) & 1.50 & 13.00 & 4.82 & \\
\hline Farm income (GH ) & 220.00 & 3600.00 & 1185.99 & 687.50 \\
\hline Non-farm income (GH ) & 0.00 & 1450.00 & 238.05 & 333.11 \\
\hline $\begin{array}{l}\text { Distance from district capital } \\
\text { to farmers residence }(\mathrm{Km})\end{array}$ & 0.00 & 33.00 & 13.10 & 8.27 \\
\hline
\end{tabular}

Appendix 4: Table 5 Descriptive statistics of categorical variables

\begin{tabular}{lll}
\hline Variable & Frequency & Percentage \\
\hline$\underline{\text { Sex }}$ & & \\
Male & 127 & 81.94 \\
Female & 28 & 18.06 \\
Total & $\mathbf{1 5 5}$ & $\mathbf{1 0 0 . 0 0}$ \\
Mobile phone accessibility & & \\
Access to mobile phone & 111 & 71.61 \\
$\begin{array}{l}\text { No access to mobile phone } \\
\text { Total }\end{array}$ & 44 & 28.39 \\
Agricultural extension service accessibility & $\mathbf{1 5 5}$ & $\mathbf{1 0 0 . 0 0}$ \\
\hline
\end{tabular}


Access to agricultural extension service 50.97

No access to agricultural extension service

79

76

49.03

Total

155

100.00

Marital status

Married

Otherwise

Total

Education up to class six and above

Access

No access

Total

$\underline{\text { Perception about changes in rainfall amount }}$

Reduction

Total

Perception about changes in temperature

Increment

Otherwise

total

Weather information accessibility

Access to weather information

No access

Total

Credit accessibility

Access to credit

No access to credit

Total
121

34

155

45

110

155

109

46

155

78.06

21.94

100.00

29.03

70.97

100.00

70.32

29.68

100.00
$96 \quad 61.94$

$59 \quad 38.06$

155

100.00

$86 \quad 55.48$

$69 \quad 44.52$

155100.00

$80 \quad 51.61$

$75 \quad 48.39$

155

\section{Copyright Disclaimer}

Copyright for this article is retained by the authors, with first publication rights granted to the journal.

This is an open-access article distributed under the terms and conditions of the Creative Commons Attribution license (http://creativecommons.org/licenses/by/3.0/). 